\title{
On Some Colour Variations and Adaptations in Actiniae.
}

\author{
By
}

Chas. L. Walton.

THE significance of the colouration of various Actiniaria has been of much interest to me for some time, and particularly the extreme variability displayed by certain of the most abundant species. Descriptions of colouration and coloured plates help but little toward elucidating these problems, the examination of numbers of the animals living in their natural environment being absolutely essential before any conclusions can be drawn.

Taken as a whole, the colouration of Actinians seems to come under the following heads :-

I. Warning.

II. Aggressive.

III. Protective.

IV. Colours with some special physiological significance.

Examination has shown that these leading features are not necessarily confined to a species, or even to an individual, which may combine them in varying degrees, though one is usually partially or wholly dominant, this being chiefly governed by the environment. In other words, I believe that the colouration of a species or individual may be adaptable to more than one end ; that local circumstances and environment govern this, and that those species which become most effectually adapted to these environmental circumstances will be everywhere found to be the most abundant.

Naturally this adaptation is not confined to colouration, but is observable in many other details, some of which will be mentioned, but the colouration is the main factor to which I wish to draw attention.

I have assembled a considerable mass of data, from which I shall here detail a selection of what I deem the most suggestive and instructive.

Actinia equina, Linn. This is quite the most abundant British species, and is extremely variable in colour; shades of red, brown, green, etc., alone or variously combined, are all abundant; several of 
the varieties are so well marked as to have been considered distinct species at various times.

While working at Aberystwyth, in Wales, I was struck, while collecting, by the fact that light had a great deal to do with the distribution of the variously coloured forms, those from exposed positions being dark red, etc., while those from under stones, or seaweed, or from caves, were mostly of light shades, or green. This has also been recorded for another member of the genus, Actinia tenebrosa, Farquhar, from New Zealand. In describing this species the author says: "This $\mathrm{i}_{\mathrm{S}}$ the southern representative of the European species $A$. equina," etc. "This species is a good example of the effects of light on the colours of animals. Full-grown individuals, in situations well exposed to the rays of the sun, have the column greenish, or brownish black, and the disk and tentacles dusky crimson, while those on the under side of overhanging stones are reddish brown or crimson, the depth of colour varying according to the amount of light that reaches them. Specimens on the vertical sides of rocks (their favourite habitat) often have a patch of reddish brown on the side turned away from the light. I found a specimen under a large stone which had evidently never been in the light: the whole animal was yellowish white with a slightly greenish tinge."

No remarks are made as to any variation in the size, number, or colour of the acrorhagi, or "marginal spherules."

Investigation of Aberystwyth specimens of $A$. equina showed that a correlation exists between environment and these organs, which are asa rule of a bright blue. M. Haime (quoted by Gosse) gives the following table of number of spherules:-

18 if 5 th cycle of tentacles not developed.

24 if 5 or $5 \frac{1}{2}$ cycles are developed.

48 if 6 cycles are developed.

My observations on some hundreds of specimens prove this to be correct if an average be taken-in effect there are considerable differences. Those individuals which are of dark shades and occur in exposed positions, tend to possess more acrorhagi than those which live in sheltered situations and which are of paler shades. In these last also the acrorhagi are fewer, smaller, and of a pale blue, whilst in the darker specimens the acrorhagi are larger, of a much deeper blue, and often irregular (bilobed, etc.) in form. The colour of the acrorhagi (lighter and darker) is of course due to the same circumstances that cause the colour differences in the rest of the individual; but the variation in size is not necessarily due to this cause, and in all proba- 
bility results from the different environment. It seems probable that these organs are defensive (possibly offensive), and they certainly contain many nematocysts, and their colour may be interpreted as "warning." These organs are not plainly visible during complete expansion, and not at all during retraction; but when the anemone is startled (if the blue basal line be touched, etc.) the tentacles are partially withdrawn and the acrorhagi are then exposed and show very plainly. A good deal has been written respecting these organs, and they have been referred to as eyes, special sense organs, etc.

Messrs. G. Y. and A. F. Dixon in treating of this species, besides mentioning irregularities of form and colour, say: "Each spherule contains a prolongation of the general body cavity, and can consequently be dilated at will," and they relate that a specimen dilated greatly, and brought the spherules into contact with the glass of the aquarium. When the organs contracted and withdrew, portions remained forming conspicuous blue spots. Examination of these showed numerous spindle-shaped cells, as described by Hollard (Ann. de Sci. Nat. Zool., 3 ser., vol. xv., p. 272), and they conclude that the anemone had evidently engaged in an attempt to sting the glass front.

I have never been able to demonstrate the discharge of nematocysts from these organs, but have on more than one occasion observed great distention of the acrorhagi, so that the increased weight caused the anemone to bend over on one side, and so bring the projecting organs into contact with objects which happened to be in close proximity.

The pale specimens with few acrorhagi are frequently as large as those darker ones with many, so that the increase must be either due to more light, or, owing to inhabiting more exposed positions, there is greater need of protection by increased batteries of nematocysts.

Sagartia miniata (Gosse) is under most conditions to be classed amongst species whose colouration is of a "warning" nature, and is amply provided with acontia which are very freely emitted. As a rule they form very conspicuous objects on the sides of rocky pools. I have examined hundreds of specimens from the North Sea, which though showing many minor variations were all of the same type even when from a depth of 40 to 47 fathoms, where the bottom was black mud (see Actiniae of the s.s. Huxley, 1907); but Mr. L. R. Crawshay showed me living specimens from the Bay of Biscay deep water in which the colouration was dull, the scarlet being absent, probably owing to lack of light. This variety entirely lacks the bright colours of the typical form. I recently found a specimen which harmonised with its surroundings in a remarkable manner. It was affixed to the 
bottom of a rock pool at East Pentire, Newquay, Cornwall. This pool was full of a growth of dark Algae, with which colonies of red species showed as thin, irregular, red streaks and lines. The $S$. miniata was very large, and its outline most irregular; the scarlet-cored outer row of tentacles so exactly resembled the red Algae, and the rest of the animal the dark Algae, as to render it most difficult of detection. I watched for some time and observed an amphipod deliberately swim into the scarlet tentacles, doubtless deceived by their resemblance to the Algae.

Cereus pedunculatus (Sagartia bellis). I had long considered that many of the numerous varieties were to be interpreted as aggressive, but a careful study of pools at Newquay, etc., brought out additional and interesting cases of adaptations.

In pools similar to that described above, a variety of a dusky umber hue was abundant, with frequently streaks and shades of red upon the inner tentacles and disk. This type predominated in those pools where the Algae were dark, with red species intermingled. When fully expanded the anemones resembled the dark weeds; when alarmed and partially contracted the red showed up, and the animals were still in harmony with their surroundings; if further irritated, the edges of the salver-shaped margin were folded over and the anemones then formed bluish purple patches against a dark background: possibly a warning colouration. A second variant found in pools only a few yards from those just mentioned was lighter in colour, more variegated, and had the tentacles merely tinged with red, or not at all. This type was found in pools where "corallines" were the main growth, and when these specimens closed, their columns were of a pink shade (seldom purple), and thus in accordance with the environment instead of in contrast, as in the last examples.

On muddy shores the summit is dark, as I have observed at Plymouth, etc. These examples could be backed by many more from varying localities. In all, the complex colouring of the disk and tentacles approximates to the colour scheme of the pool, or portion of pool in which the individual has its habitat. I quote from my notes made on the rocks at Polzeath, near Padstow, Cornwall: "C.pedunculatus is fairly abundant on this (the Pentire) side of the bay, and I have examined a considerable number. The rocks hereabouts are reddish or greenish, and the pools are often coated with pink Algae. In the first I examined a dull red specimen was expanded, and just the shade of numerous tufts of the brown seaweeds growing around it; when closed the margin was of a pink hue, exactly that of the rock around it. Near by were others growing amidst pink 
corallines, the tips of which were dead and white; these were of a dull pink, freckled all over with white, and thus so resembled the corallines as to quite deceive me at first.

"Many were expanded at the mouth of cracks and crevices, into which they retired when touched; and most of these had the summit covered with fragments of shell, etc., attached to the suckers of the upper portion of the column, so that when contracted there remained no sign of the anemone. I ascertained that in these the colour of the under side of the waved margin was not in agreement with the environment.

"Throughout numerous pools in ever-changing conditions, this species in each case varied to suit the colour scheme, importing shades of red or yellow, or both, in threads and streaks, and so on through innumerable variations."

I have frequently had to resort to feeling before I could be sure whether what I saw was a tuft of some seaweed or a specimen of C. pedunculatus.

That this resemblance is of protective value is highly probable, but from numerous observations, both under natural conditions and in aquaria, of small Crustacea mistaking the anemones for Algae and so being caught and devoured, I consider it to be also, if not even predominantly, aggressive.

Specimens living under stones are usually of small size, and when so situated that they can receive even a modicum of light are in colour merely pale editions of the prevailing local varieties; but when, as is frequently the case, specimens are obtained from beneath several layers of stones and weeds and thus have lived in darkness, the colours are usually light shades of chrome-yellow, together with crimson and scarlet, generally in lines and streaks, the columns as a rule colourless. A certain proportion of these shades frequently forms some portion of the mixed colouration of the surface forms, and the curious predominance in cases where adaptive and selective conditions are in abeyance may point to a form originally so coloured.

Gephyra dohrnii, von Koch, I consider to be a true instance of protective resemblance. At the Marine Biological Laboratory, Plymouth, I recently examined several specimens living upon Eunicella cavolini, von Koch. An adult exactly agreed with the general tone of the Eunicella, but a smaller and younger one did not accord so well, being paler, and when expanded showed a number of irregular opaque white streaks upon the disk and tentacles. In the adults there were merely a few specks in the area of the mouth. This may also point to an ancestry not resembling the Eunicella in colour, or at any rate 
striped in the usual Sagartian style? That Eunicella is in a great measure protected from fish attacks finds support in the colouration of specimens of Tritonea plebeia and Ovula patula that dwell thereon.

A. C. Haddon, in his account of Gephyra from the Irish coast, figures three-colour variants, all of which occurred upon Tubularia. Fig 3, pl. xxxi., shows a "cherry-coloured" variety, which must have been in close accord with the "polyps" of the Tubularia; the others are much lighter and more resemble the forms from Eunicella. Andres figures a yellow Gorgonid, and the anemone whitish tinged with yellow, but his description gives "Colonna carnicina."

Sagartia undata (S. troglodytes). Although fairly well acquainted with several varieties, I regret that since I became interested in this subject I have not met with it in any abundance, and hence cannot say much regarding this most variable species. Gosse says (p. 92): "In the shallow pools that floor the largest caves at St. Catherine's, Tenby, the varieties scolapacina and aurora spread their pretty blossom faces at the bottom of the clear water. And yet it is not easy to discover them even when scores are thus exposed, for the mottled colouring of the disk and tentacles is so like that of the sand and mud of the pools that even a practised eye may overlook them without the closest searching." Others with orange disk, or tentacles, are evidently warningly coloured. Gosse (p. 91) gives "variety hesperus. Wholly pure white, gradually acquiring colour in a confinement of some months" (Lundy, W. Brodrick in litt.).

Tealia coriacea (crassicornis). Mr. F. Slade, of Horniman's Museum, in a letter to my friend Dr. Fleure, noted that specimens of Tealia coriacea (crassicornis) sent from Aberystwyth were better coloured and altogether better animals than those from the chalk of Sussex, and this I have since seen for myself. Gosse (p. 211) says of deep water specimens, "all colour lost in a semi-pellucid dusky grey . . . and specimens usually very large." I have examined large numbers of this deep-water form. H. N. Moseley describes from the Severn estuary, near Aust and New Passages, large numbers of Actinia, and Tealia (near Weston-super-Mare, very common), the colours of all dull, especially Actinia which were dirty white or pale olive, and the Tealia transparent green. Near Aust were found a few Tealia vivid red, nearly as bright as marine specimens. "They were attached to a rocky channel, and when the tide fell a constant stream of water came from a large pool above in which the mud settled and clear water flowed off."

Anemonia sulcata is a decidedly puzzling species. Showing considerable variation, there are two varieties which are predominant:

NEW SERIES.-VOL. IX. NO. 2. OCTOBER, 1911. 
the green with purple-tipped tentacles, and the brown and grey. Both these are most abundant, frequently inhabiting the same pool. The species is provided with very powerful sting cells (I have myself been well "nettled" when handling large specimens) and is evidently sufficiently protected from fish attacks, or at any rate to a considerable extent. Both varieties when under water present a decided resemblance to masses of Algae, and doubtless obtain much food in the form of deluded Crustacea, and I am inclined to consider the colouration as partially aggressive, with secondary warning colours in the purple tips of the tentacles, and the occasional scarlet area on the lower portion of those organs. It is to be noted that these characters usually only accompany the green variety named smaragdina by Gosse. The scarlet area on the tentacles is mentioned by Gosse (p. 162) as occurring at Herm, and I have seen it in varying degrees on several occasions. I will give one instance from my notes. Near low-water level at Polzeath (N. Cornwall) I came across two enormous individuals attached side by side. The columns were rich purple-brown, the tentacles some four or five inches in length, a most vivid green, and purple-tipped, while the bases" of the tentacles resembled flamecoloured silk. I touched them with my finger, knowing that irritation usually produces an increase of brilliance in this species; the tentacles at once bent inward, thus exposing the lustrous, glowing areas to plainer view. F. G. A. Stuckey in his Review of New Zealand Actiniara says of Anemonia olivacea, Hutton: "This species is found in rock pools, often inhabiting quite small pot holes on the upper part of the rocks. Its colour is strongly protective." I have examined numbers on the west coast of the $\mathrm{N}$. Island, and consider that this also is a case of "aggressive" colouration, as it greatly resembles tufts. of green Algae.

I had frequently noted in many Sagartids that in some specimens. the acontia would be emitted on the slightest provocation, while in others they were only protruded after severe irritation. I now regard this as largely due to varying environmental conditions. Those individuals which have been exposed to constant friction only emit the acontia after considerable irritation, whilst those which have been living in quiet and undisturbed surroundings emit the acontia with freedom and at the least touch. My reference to constant friction applies to individuals which, living within tide marks, are exposed to constant boil of surf, causing abrasion by shingle, etc., or constantly brushed by Algae.

- This control of acontia is closely connected with and analogous to the control of nematocysts, etc., referred to in a former paper ("Notes 
on the Habits of some Sea Anemones," by H. J. Fleure and C. L. Walton), and is the result of differentiating reactions and a persistent inhibitory stimulus due to the constant repetition of such causes as induced the same, and which alone probably prevent its lapsing. We have already shown that such impressions are evanescent, and it would appear that the whole tissues of these animals are in what may perhaps be termed a more or less plastic state, and hence (at least in many forms) varying environmental conditions readily affect them, and adaptations. rapidly result. Hence the abundance of very variable species.

\section{LITERATURE CITED.}

1. Andres, A. Le Attinie, Fauna u. Flora Golf. Neapel, IX, 1883.

3. Drxon, G. Y. and A. F. Report on Marine Invertebrate Fauna near Dublin. Proc. Roy. Irish Acad., 3rd Series, vol. II, p. 19.

4. Farquhar, H. Preliminary Account of some New Zealand Actinians. Lin. Soc. Journ. Zool, vol. xxvi, 1898.

5. Fleure, H. J., and C. L. Walton. Notes on the Habits of some Sea Anemones. Zool. Anzeiger, Bd. xxxi, No. 7, pp. 212-20, 1907.

6. Gosse, P. H. Actinologia Britannica, 1860.

7. Haddox, A. C. Revision of British Actiniae, Part I. Trans. Roy. Dub. Soc., vol. IV, ser. II, No. v, 1889.

8. Moseley, H. N. Quart. Journ. Micr. Sci., xIII, 1873.

9. Stuckey, F. G. A. Review of New Zealand Actiniaria. Trans. N.Z. Institute, vol. XLI, p. 381, 1908.

10. Walton, C. L. Actiniae collected by s.s. Huxley. Journ. Mar. Biol. Assoc., vol. viII, No. 2, 1908. 